\title{
Modelling Urban Sprawl Using Remotely Sensed Data: A Case Study of Chennai City, Tamilnadu
}

\author{
Rajchandar Padmanaban ${ }^{1, *}$, Avit K. Bhowmik ${ }^{2}$, Pedro Cabral ${ }^{1, *}$, Alexander Zamyatin ${ }^{3}$, \\ Oraib Almegdadi ${ }^{4}$ and Shuangao Wang ${ }^{5}$ \\ 1 NOVA Information Management School (NOVA IMS), Universidade Nova de Lisboa, 1070-312 Lisbon, \\ Portugal \\ 2 Stockholm Resilience Centre, Stockholm University, Kraftriket 2B, SE-104 05 Stockholm, Sweden; \\ avit.bhowmik@su.se \\ 3 Tomsk State University, Lenin Avenue 36, 634050 Tomsk, Russia; zamyatin@mail.tsu.ru \\ 4 Institute for Geoinformatics (IFGI), Westfälische Wilhelms-Universität, Heisenbergstraße 2, 48149 Münster, \\ Germany; Almegdadi.oraib@gmail.com \\ 5 School of Humanities And Social Sciences, Nanyang Technological University, 14 Nanyang Drive, \\ Singapore 637332, Singapore; wangshuangao@gmail.com \\ * Correspondence: rajchandar07@gmail.com (R.P.); pcabral@novaims.unl.pt (P.C.); \\ Tel.: +351-967-843-586 (R.P.); Tel.: +351-213-828-610 (P.C.)
}

Academic Editor: Kevin H. Knuth

Received: 4 January 2017; Accepted: 5 April 2017; Published: 7 April 2017

\begin{abstract}
Urban sprawl (US), propelled by rapid population growth leads to the shrinkage of productive agricultural lands and pristine forests in the suburban areas and, in turn, adversely affects the provision of ecosystem services. The quantification of US is thus crucial for effective urban planning and environmental management. Like many megacities in fast growing developing countries, Chennai, the capital of Tamilnadu and one of the business hubs in India, has experienced extensive US triggered by the doubling of total population over the past three decades. However, the extent and level of US has not yet been quantified and a prediction for future extent of US is lacking. We employed the Random Forest (RF) classification on Landsat imageries from 1991, 2003, and 2016, and computed six landscape metrics to delineate the extent of urban areas within a $10 \mathrm{~km}$ suburban buffer of Chennai. The level of US was then quantified using Renyi's entropy. A land change model was subsequently used to project land cover for 2027. A 70.35\% expansion in urban areas was observed mainly towards the suburban periphery of Chennai between 1991 and 2016. The Renyi's entropy value for year 2016 was 0.9 , exhibiting a two-fold level of US when compared to 1991. The spatial metrics values indicate that the existing urban areas became denser and the suburban agricultural, forests and particularly barren lands were transformed into fragmented urban settlements. The forecasted land cover for 2027 indicates a conversion of 13,670.33 ha (16.57\% of the total landscape) of existing forests and agricultural lands into urban areas with an associated increase in the entropy value to 1.7 , indicating a tremendous level of US. Our study provides useful metrics for urban planning authorities to address the social-ecological consequences of US and to protect ecosystem services.
\end{abstract}

Keywords: urban sprawl; random forest classification; spatial metrics; Renyi's entropy; sustainability; land change modelling; remote sensing; urban growth model; Chennai

\section{Introduction}

A rapid global increase in human population has triggered the migration of rural poor towards the cities for a better standard of living, education and income [1]. By 2030 the world's population is 
expected to increase by $72 \%$ with a $175 \%$ upsurge in urban areas $(>100,000$ inhabitants) [2]. The migrant rural poor often encroach the cheap suburban peripheries [3,4] and, consequently, the cities expand to accommodate immigrants as well as to create employments by intensification of industries [4]. This eventually leads to urban sprawl (US) and the uneven development, through the conversion of suburban lands to built-up settlements [5].

US entails adverse impacts on ecosystem services by diminishing agricultural lands, water bodies and forests [1]. US has also been associated with increasing risks from environmental externalities, such as energy crisis, biodiversity loss and floods [6]. Particularly, in developing countries like India, where $60 \%$ of the total population (approximately 70 million) are predicted to live in urban areas by 2030, US may entail disastrous impacts on ecosystem and biodiversity [7]. The quantification of the extent and level of US are thus essential for Indian cities to support sustainable planning, policies and efficient design of cities [8]. However, with a few exceptions, such studies are scarce for India [9-13].

Globally, remote sensing imageries and techniques showed considerable potentials for urban growth and US analysis [14-16]. Landuse and landcover classes (LULC) are important indicators for understanding the connections between environment and human activities [17-21], which can be efficiently obtained from satellite imageries through image classification. These are particularly useful for countries like India, where ground monitoring data are scarce and inaccessible [18]. Moreover, the availability of remotely sensed data from multiple dates enables to carry out studies on multitemporal urban modeling $[9,17,18,22-28]$. The extent of urban areas can be automatically identified from satellite imagery using machine learning algorithms [29]. Change detection analysis can be carried out through the use of transition matrices, which measure the changes between two LULC maps from different periods of time. They, in turn, help to quantify the extent of US through the differences between urban extent across multiple temporal periods [17]. In addition, the spatial and physical characteristics of urban features, urban patterns and their forms may be quantified using several landscape metrics [25]. These metrics can be derived from thematic maps computed from remotely sensed data [26]. Furthermore, Entropy values, such as Shannon's Entropy and Renyi's Entropy, which are widely used to characterize and identify the degree of spatial dispersion and concentration of urban areas [30-37], can also be computed from remotely sensed images and effectively used to quantify the level of US [35].

In this study we quantified the extent and level of US within a $10 \mathrm{~km}$ suburban buffer of an Indian megacity, i.e., Chennai, Tamilnadu, using Landsat imageries from 1991, 2003 and 2016. We quantified: (1) the changes in US extent between 1991 and 2016; (2) the US level and patterns using entropy and landscape metrics; and (3) predicted the US extent and level for 2027 using a land change model.

\section{Study Area}

Chennai is the capital city of Tamilnadu state, India, and the gateway of south India (Figure 1). The geographical location of Chennai spans between $13.04^{\circ} \mathrm{N} 80.17^{\circ} \mathrm{E}$ with an elevation between $6 \mathrm{~m}$ and $60 \mathrm{~m}$ above the mean sea level. It covers an area of about 42,600 ha [16]. This is India's fourth largest city, with a total population of 8,233,084 according to the 2011 India census [16], which has doubled during in the last two decades [15]. Chennai is also one of the principal business hubs of India with an unprecedented expansion of industries and infrastructures [38]. With several United Nations Educational, Scientific and Cultural Organization (UNESCO) world heritage sites, Chennai is one of the main tourist hubs [15]. The suburban periphery of the city represents a unique biodiversity hotspot. The coastal area (Marina beach) at the East represents a unique mangrove ecosystem [39], whereas the dense forest at the West represents a rare composition of tropical flora and fauna [40].

The city of Chennai is one of the fastest growing urban areas in the world during the last three decades [15]. This has resulted in an uncontrolled US with negative consequences regarding air pollution, housing scarcity, overcrowding, encroachment, slums, unregulated disposal of waste, increasing water scarcity and pollution [14]. The US has also lead to various adverse environmental 
impacts, such as higher energy exploitations, disturbance of species diversity, increasing flood risk, and ecosystem fragmentation [6].

The spatial trend of US in Chennai is towards two peripheral districts, i.e., Tiruvallur (Northwest Chennai) and Kanchipuram (Southwest Chennai) [16]. Consequently, we selected an area constituting $82,488.16$ ha, which covers the geographic extent of the Chennai city and a $10 \mathrm{~km}$ suburban buffer, i.e., Tiruvallur and Kanchipuram districts, to study US.

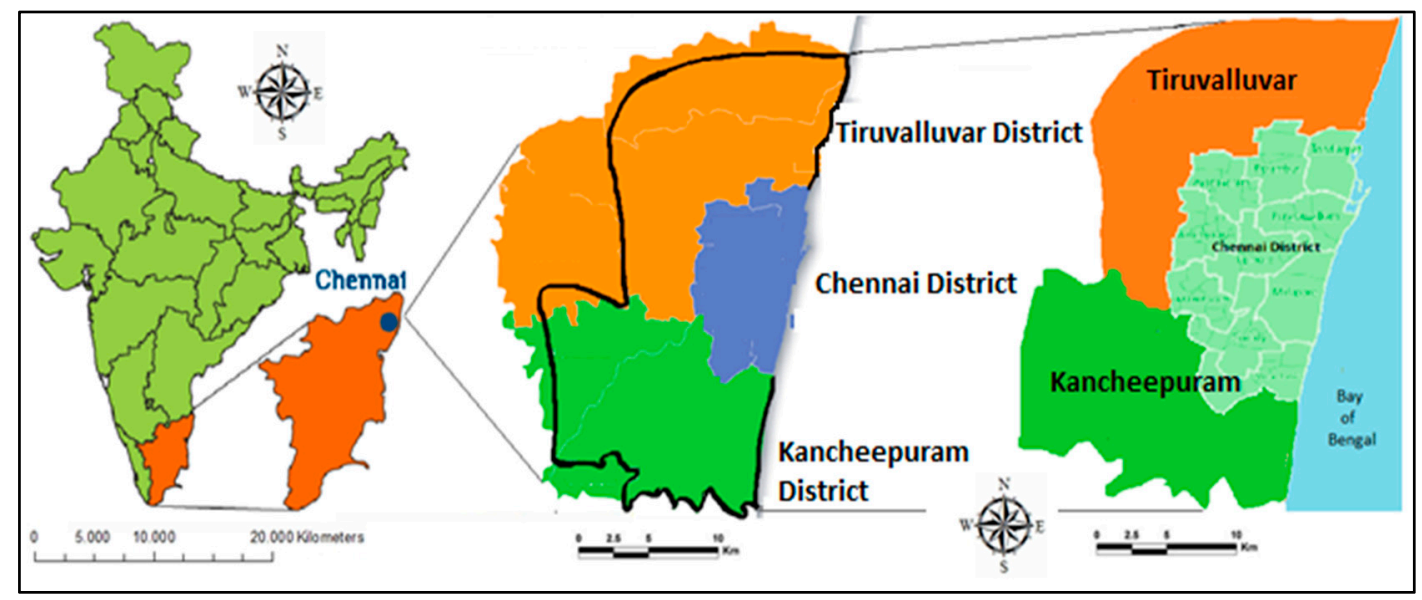

Figure 1. The study area covering Chennai city and $10 \mathrm{~km}$ sub-urban buffer.

\section{Materials and Methods}

\subsection{Data and Pre-Processing}

We used Landsat Thematic Mapper (TM) and Enhanced Thematic Mapper (ETM+) images with a $30 \mathrm{~m}$ spatial resolution covering the temporal scenes from 1991, 2003, and 2016 (Table 1). The images were freely downloaded from the Unites States Geological Survey (USGS) portal [41] in GeoTIFF format and georeferenced using the World Geodetic System (WGS) 1984 coordinate reference system. The data were initially geo-corrected and rectified, and cropped to the study area (Figure 1). The image pre-processing was performed using Environment for Visualizing Images (ENVI) software package (Version 5.1) [42,43].

Table 1. A technical description of the Landsat TM and ETM+ imageries used in this study.

\begin{tabular}{ccc}
\hline Date & Sensor & Path/Row \\
\hline 25 August 1991 & Landsat-5 TM & $142 / 51$ \\
9 May 2003 & Landsat-7 ETM+ & $142 / 51$ \\
4 July 2016 & Landsat-7 ETM+ & $142 / 51$ \\
\hline
\end{tabular}

\subsection{Landuse and Landcover (LULC) Mapping, and Accuracy Assessment}

We applied a Random Forest (RF) machine learning algorithm on the pre-processed TM and ETM+ images for LULC classification [44] (Figure 2). The RF algorithm in R involves the following steps:

1. Create the stack for the available raster data;

2. Create n-tree bootstrap samples from the raster data;

3. Apply an unpruned classification grown for each of the bootstrap samples according to the Digital Number (DN) values of the raster data;

4. Create $\mathrm{N}$ number of polygons according to the $\mathrm{DN}$ raster values;

5. Assign different color bands to the several classes; 
6. Display the unsupervised classification.

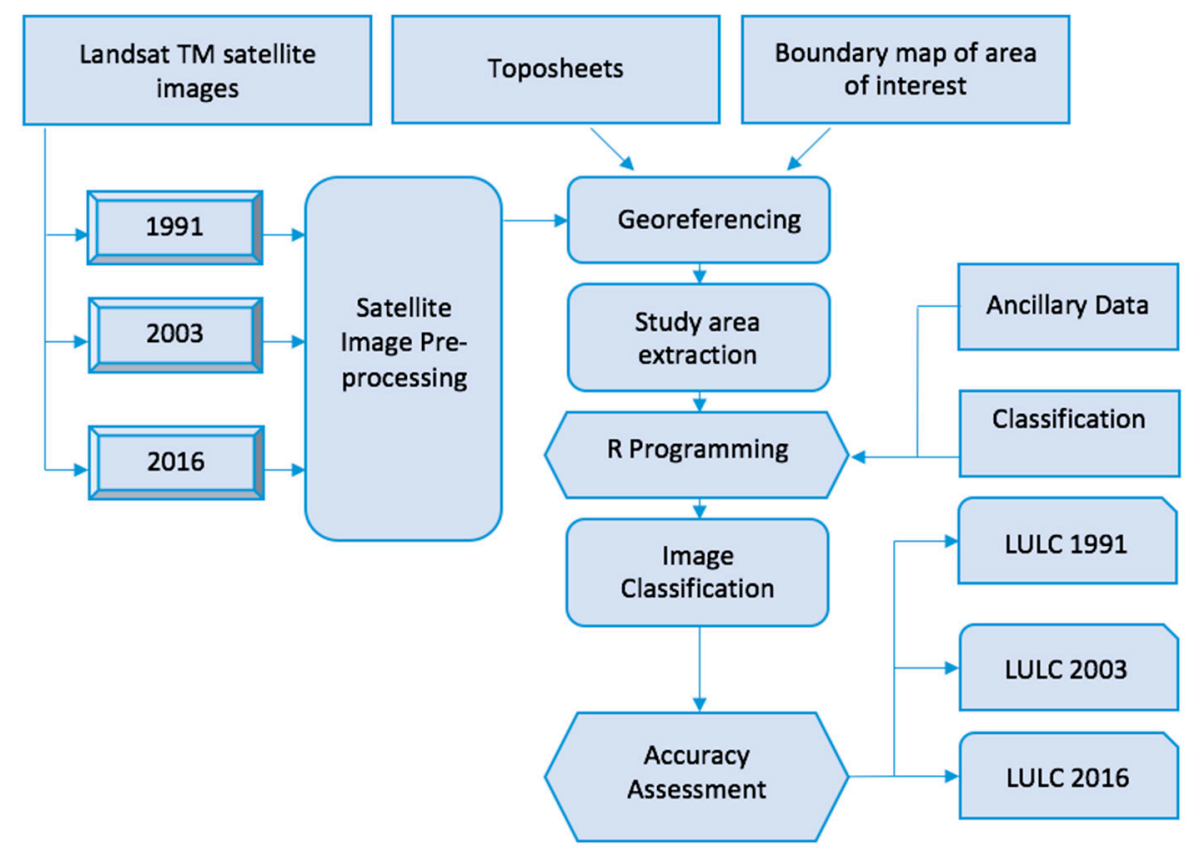

Figure 2. Flow-chart for image processing, classification and accuracy assessment.

In a next step, the spatially-cohesive features of the classified images were homogenized using a segmentation algorithm and the regions with the maximum homogeneity were delineated [45]. The regions with five distinct LULC classes (Table 2) were delineated for 1991, 2003 and 2016 by providing the minimum and maximum threshold values of pixels obtained from the RF, and the population thresholds for pixels corresponding to a LULC class [9]. We used the RF package in $R$ for the classifications of LULC [46]. The classified image homogenization and delineation of LULC regions were performed using the ENVI (Version 5.1) feature extraction tool [43,47].

Table 2. Landuse and landcover (LULC) nomenclature.

\begin{tabular}{lcc}
\hline No & LULC Classes & Land Uses Included in the Class \\
\hline 1 & Water bodies & Rivers, reservoir, lakes, streams, open water, and ponds \\
2 & Urban & Roads, airports, and built-up areas \\
3 & Agriculture & Agriculture lands and plantations \\
4 & Bare land & Dry lands, non-irrigated lands, ready for construction, and real estate plots \\
5 & Vegetation & Forests and shrubs \\
\hline
\end{tabular}

The accuracy of the image classification was assessed using the kappa coefficient (KC) $[35,36]$. We compared the classified images with the ground truth data obtained from Google Earth image of 2016 and the landuse and landcover map of 2005 from the Indian Geo-platform of ISRO-Bhuvan (http://bhuvan.nrsc.gov.in) [16]. Subsequently, a confusion matrix and KC were calculated using eCognition Developer (8.7) for each of the classified images of the three years [48].

\subsection{Quantification of Extent and Level of Urban Sprawl (US)}

\subsubsection{Extent of US}

We calculated six landscape metrics to quantify the extent of US between 1991 and 2027 in the Chennai city (see Table 3 for details on the landscape metrics) [49]. These metrics quantify the spatial 
characteristics and pattern of the classified LULC areas using three levels, i.e., the patch level, class-area level and landscape level. The landscape metrics were computed in the freely available FRAGSTATS software package (Version 4.2) [50].

Table 3. Description and formulae for spatial metrics computation.

\begin{tabular}{|c|c|c|c|}
\hline Landscape Metrics & Formula & Description & Range \\
\hline Class Area Metrics (CA) & $\begin{array}{l}C A=\sum_{j=1}^{n} a_{i j}\left(\frac{1}{10000}\right) \\
a_{i j}=\text { area in } \mathrm{m}^{2} \text { of patch } i j .\end{array}$ & $\begin{array}{l}\text { Total amount of class } \\
\text { area in the landscape }\end{array}$ & $C A>0$, without limit \\
\hline Number of Patches (NP) & $\begin{array}{l}N P=n_{i} \\
n_{i}=\text { total number of patches in the } \\
\text { area of patch type } i \text { (class). }\end{array}$ & $\begin{array}{l}\text { Number of patches of } \\
\text { landscape classes (Built } \\
\text { up and non-built-up) }\end{array}$ & $N P \geq 1$, without limit \\
\hline Largest patch Index (LPI) & $\begin{array}{l}L P I=\frac{\max _{j=1}^{n}\left(a_{j i}\right)}{A}(100) \\
a_{i j}=\text { area in } \mathrm{m}^{2} \text { of patch } i j \text { and } \\
A=\text { landscape area in total }\left(\mathrm{m}^{2}\right)\end{array}$ & $\begin{array}{l}\text { Percentage of the } \\
\text { landscape included by } \\
\text { the largest patch }\end{array}$ & $0<L P I \leq 100$ \\
\hline $\begin{array}{l}\text { Clumpiness Index } \\
\text { (CLUMPY) }\end{array}$ & $\begin{array}{l}\text { Clumpy }=\left[\left(G_{i}-P_{i}\right) / P_{i}\right. \\
\text { for } G_{i}<P_{i} \& P_{i}<5, \text { else } \\
\left.G_{i}-P_{i} / 1-P_{I}\right] \\
g_{i i}=\text { number of like joins among } \\
\text { pixels of patch type, } i \text { based } \\
\text { double-count process and } \\
g_{i k}=\text { number of like joins among } \\
\text { pixels of patch type, } k \text { based } \\
\text { double-count process, } \\
P_{i}=\text { amount of the landscape } \\
\text { occupied by patch type }\end{array}$ & $\begin{array}{l}\text { Measure the clumpiness } \\
\text { of patches in urban areas }\end{array}$ & $-1 \leq C L U M P Y \leq 1$ \\
\hline $\begin{array}{l}\text { Fractal Index } \\
\text { Distribution } \\
\text { (FRAC_AM) }\end{array}$ & $\begin{array}{l}A M=\sum_{j=1}^{n}\left[x_{i j}\left(a_{i j} / \sum_{j=1}^{n} a_{i j}\right)\right] \\
a_{i j}=\text { area in } \mathrm{m}^{2} \text { of patch } i j .\end{array}$ & $\begin{array}{l}\text { To measure area } \\
\text { weighted mean patch } \\
\text { fractal dimension }\end{array}$ & $1 \leq F R A C_{-} A M \leq 2$ \\
\hline Contagion & $\begin{array}{l}\text { Contag }=[1+ \\
\sum_{i=1}^{m} \sum_{k=1}^{m}\left[\left(p_{i}\right)\left\{g_{i k} / \sum_{k=1}^{m} g_{i k}\right\}\left\{\ln \left(p_{i}\right)\right.\right. \\
\left.\left[g_{i k} / \sum_{k=1}^{m} g_{i k}\right] / 2 \ln (m)\right] 100 \\
p_{i}=\text { amount of the landscape } \\
\text { employed by patch type }(i) \text { class } \\
\text { and } g_{i k}=\text { number of like joins } \\
\text { among pixels of patch type, } i \text { and } \\
k \text { based double-count process, } \\
m=\text { number of patch classes } \\
\text { (types) existing in the landscape }\end{array}$ & $\begin{array}{l}\text { Defines the heterogeneity } \\
\text { of a landscape }\end{array}$ & $\begin{array}{c}\text { Percent }<\text { Contagion } \\
\leq 100\end{array}$ \\
\hline
\end{tabular}

\subsubsection{Level of US}

Renyi's Entropy (RE) [35,51,52] was calculated to estimate the level of US between 1991 and 2016. First, we aggregated the classified LULC map into two classes, i.e., built-up and non-built-up. Then, the total number of patches $(N)$ for the built-up and non-buit-up areas and their corresponding perimeters $\left(P_{i}\right)$ were computed. Finally, a $H$ order entropy value $H_{\alpha}$ as calculated using (1), where $\alpha \geq 0$ and $\alpha \neq 0$ :

$$
H_{\alpha}=\frac{1}{1-\alpha} \ln \sum_{i=1}^{N} P_{i}^{\alpha}
$$

The RE values $(H \alpha)$ varied from 0 (indicating very dense distribution of aggregated classes) to 1 (indicating dispersed distribution across the study area) [52]. The changes in RE values for the built-up patches during three decades, i.e., 1991-2016, represented the change in the US level (i.e., dispersion of urban areas) for the Chennai city, Tamilnadu. 


\subsection{Prediction of Urban Extent for 2027}

The prediction of future urban extent was performed using the Land Change Modeler available in the TerrSet (formerly IDRISI) software (Version 18.3) [53]. The land change model was calibrated to predict the extent of Chennai for 2016 using a four-step procedure: (1) quantification of urban change between 1991 and 2003; (2) transition modelling between 1991 and 2003; (3) urban extent prediction for 2016; and (4) validation using the classified LULC for 2016 as reference data (Figure 3).

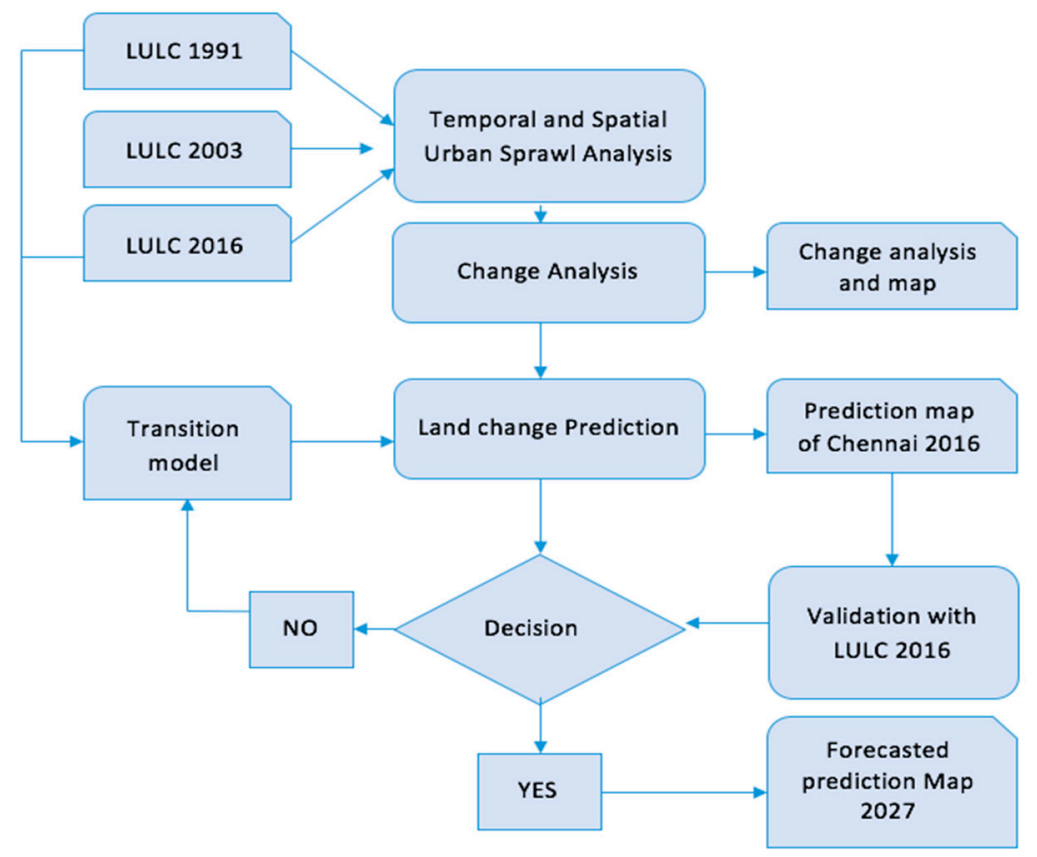

Figure 3. Methodology applied for the prediction of urban sprawl extent and level for 2027.

LULC change analysis was conducted using the LULC maps for 1991 and 2003 as primary inputs [53]. The land changes between 1991 and 2003 were quantified and the losses and gains among the LULC classes were obtained. Then, a change map between 1991 and 2003 using a multilayer perception neural network algorithm was computed. This included constraints and factors used in the urban extent prediction. Next, a change map was generated for the period 2003-2016 using the computed changes between 1991 and 2003. Subsequently, a change probability grid for the 2003-2016 period was obtained. In a final step, we calibrated the urban extent prediction model (UEPM) using a Markov Chain, which combined the change map with a change probability grid for the period 2003-2016.

The urban extent of Chennai was predicted for 2016 applying the UEPM. The predicted urban extent was compared with observed LULC map for 2016 using Kappa variations, i.e., $K_{\text {location }}$ and $K_{\text {quantity }}$ [54-59]. If acceptable values for these kappa variations are obtained, then we proceed to 2027 simulation [55]. The calibrated and validated UEPM was applied to predict the urban extent of Chennai for 2027 using the urban extent for 2016 as baseline and combining the change map and change probability grid between 2016 and 2027 computed using the procedure described above. The year 2027 was selected for our prediction because we wanted to use a 10-year horizon for this study. The transition probabilities used in the modeling process were obtained using the period 1991-2003 which is very similar to the period from 2016-2027 used in the prediction. 


\section{Results and Discussion}

\subsection{The Extent and Patterns of US in Chennai between 1991 and 2016}

The LULC maps of three different periods show that the study area has experienced a remarkable land cover change between 1991 and 2016 (Figure 4). From 1991 to 2016 the growth of urban, i.e., built-up, areas were more than three-fold, i.e., an increase of about 37,919.81 ha (Table 4). This transformation influenced several classes, especially the agriculture and vegetation land, which decreased by about 3802.70 ha (4.61\%) and 9923.32 ha (12.03\%), respectively. The bare land exhibited the highest amount of decrease, i.e., 30.3\% and thus indicate that the growth of urban areas were accommodated mostly by diminishing bare lands. The water bodies increased by 1451.79 ha between 1991 and 2003, but decreased slightly between 2003 and 2016 (about 651.65 ha). These results confirm that the urban areas in Chennai are extending toward the peripheral region of Kanchipuram (South Chennai) and to the Thiruvalluvar (North Chennai) district area, and thus a substantial US. Although, the US was mostly accommodated by the loss of bare lands, this growth has greatly impacted the landscapes with the loss of valuable vegetation and agriculture lands.
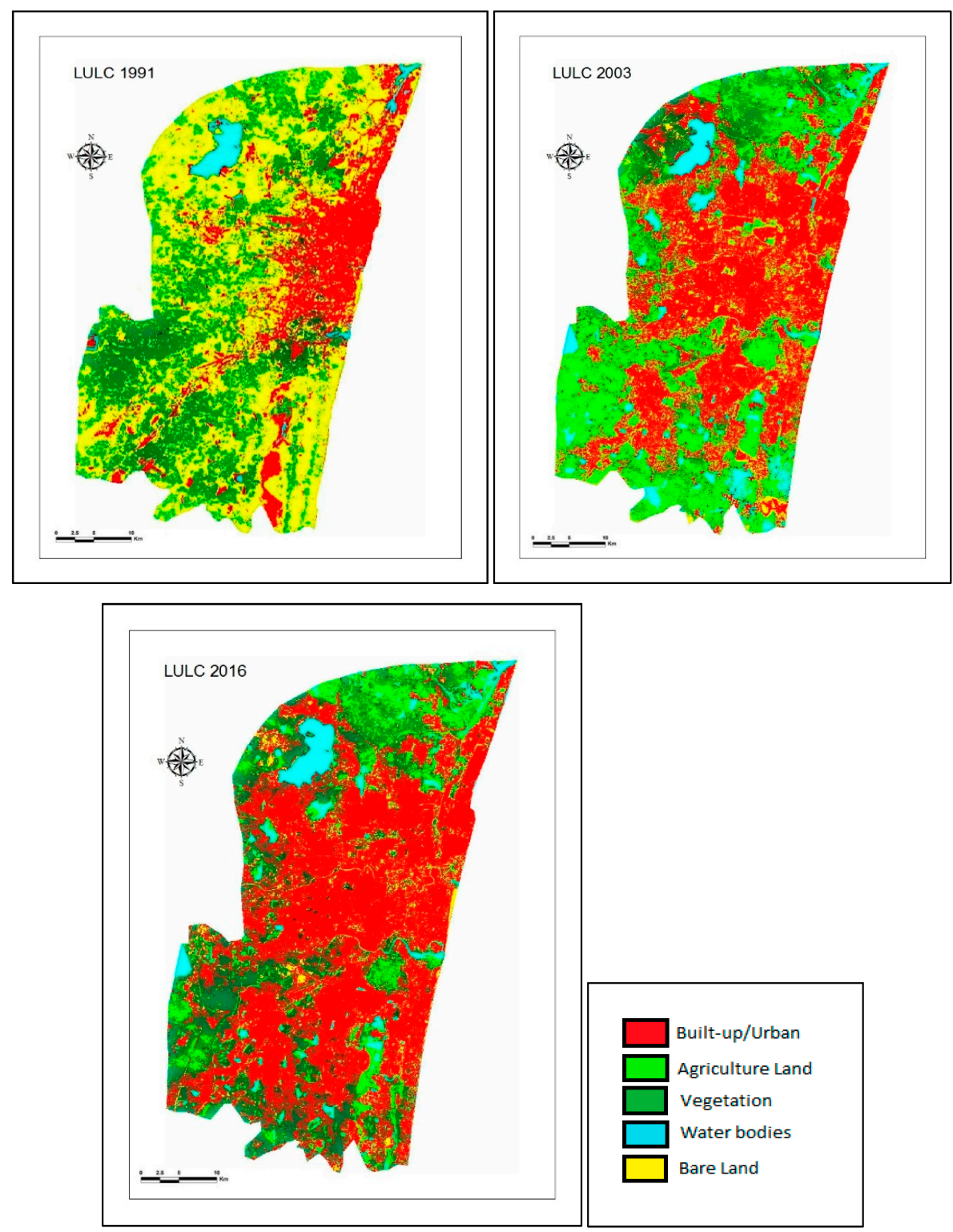

Figure 4. Landuse and landcover (LULC) maps for 1991, 2003, and 2016 in Chennai. 
The Chennai coastline has also experienced a remarkable urban growth between 1991 and 2016 (Figures 1 and 4). Almost all the coastline of the study region was covered by urban settlements by 2016 by an alarming rate of conversion of the mangrove forest area (Figure 4). These results are in line with $[60,61]$, which demonstrated negatively impacted mangrove forests and the Savukku plantations in the periphery of Chennai. This vegetation provides important ecosystem services, such as protection from Tsunami, cyclones, and other ecological disasters [62]. As a result, we anticipate environmental externalities and biodiversity loss for Chennai, such as habitat loss for native species including the Great Indian Horned Owl, spotted deer, mongooses, bonnet monkeys, and golden jackals [14].

Table 4. Landscape indices and their changes in percent.

\begin{tabular}{ccccccc}
\hline \multirow{2}{*}{ Metrics } & \multicolumn{5}{c}{ Year } & \multicolumn{5}{c}{ Changes in Urban Structure } \\
\cline { 2 - 7 } & $\mathbf{1 9 9 1}$ & $\mathbf{2 0 0 3}$ & $\mathbf{2 0 1 6}$ & $\mathbf{\Delta \%} \mathbf{~ 1 9 9 1 - 2 0 0 3}$ & $\mathbf{\Delta} \mathbf{\%}=\mathbf{2 0 0 3 - 2 0 1 6}$ & $\mathbf{\Delta} \mathbf{~ = ~ 1 9 9 1 - 2 0 1 6}$ \\
\hline CA & $20,110.61$ & $39,965.51$ & $58,030.42$ & 98.72 & 45.20 & 188.5 \\
NP & 289 & 354 & 477 & 22.49 & 34.74 & 65 \\
LPI & 2.14 & 4.87 & 6.78 & 127.57 & 39.21 & 216.8 \\
Clumpy & -1 & 0.6 & 0.8 & 160 & 33.33 & 180 \\
FRAC_AM & 1.12 & 1.27 & 1.83 & 13.39 & 44.09 & 63.3 \\
CONTAG & 72.32 & 68.43 & 71.24 & 6.66 & 4.10 & 1.4 \\
\hline
\end{tabular}

Additionally, the degradation of forest may lead to an increase in city temperature and air pollution levels [63,64], e.g., recent studies have revealed Chennai as one of the highly air polluted cities in India [65].

The obtained KC for the LULC maps of 1991, 2003, and 2016 were $0.92,0.97$, and 0.92, respectively. These values indicate a high accuracy level for landuse and landcover classification $[9,56]$.

The landscape metrics indicate that the urban class area (CA) has increased by $98.72 \%$ and $45.20 \%$ between 1991 and 2003, and 2003 and 2016, respectively (Table 4). The NP for urban settlements has shown an associated increase of 22.49\% and 37.74\% between 1991 and 2003 and 2003 and 2016, respectively. These values indicate a high level of land fragmentation.

The LPI increased by 127\% between 1991 and 2003. This high value due to the large urban patches indicates a compact urban growth for the centre, but fragmented and dispersed urban growth in the fringe areas, i.e., US. LPI continued to increase from 2003 to 2016 (39.21\%), confirming the continuation of US process for Chennai.

The CLUMPY in 1991 was -1 , showing a maximally disaggregated urban patch. However, these values were 0.6 and 0.8 in 2003 and 2016, respectively, indicating an aggregation or clumpiness of urban patches. Likewise, FRAC_AM increased between 1991 and 2003 as a result of contained urban growth with reasonable shape complexity (the values for this metric were marginally greater than 1). Nevertheless, the FRAC_AM value between 2003 and 2016 was 1.83 (increased by 44.09\%), indicating that the landscape had a higher range of urban growth and more dispersed urban sprawl than the 1991-2003 period.. The decrease in the CONTAG value between 1991 and 2003 indicates a high fragmentation of the landscape. However, this value increased slightly between 2003 and 2016 $(4.10 \%)$ showing that the fragmented urban area has become denser than the 1991-2003 period.

\subsection{Change in US Level in Chennai}

The Renyi's entropy value for the Chennai was 0.4 in 1991, indicating rather moderately aggregated urban settlements, i.e., negligible US level. However, in 2003 the entropy value reached the threshold value of 0.5 , indicating the initiation of dispersion, i.e., US, in Chennai [35,57]. In 2016, the entropy value was 0.9 , which indicates a very high level of US in the periphery of Chennai. This high level of US in 2016 may directly relate to the haphazard encroachment of the urban fringe. This, in further, relates to the rapid population growth and land scarcity in the city centre, which were claimed to be the major reasons behind the US in the peripheral districts of Chennai [1]. 
The high level of US adds strain to urban infrastructure, such as sewage water disposal and waste management, and directly lead to urban water and soil pollution [66]. Recent studies showed that the threat of pollution of the Cooum river [67] and the coastal zones in Chennai have been increased towards 2016 due to the uncontrolled discharge of untreated sewage wastes from domestic and commercial activities, which may be linked to the high level of US observed in our study [37]. Moreover, the high level of US hampers waste management, e.g., $0.71 \mathrm{~kg}$ of daily garbage per capita in Chennai are currently incinerated at Perungudi and Kodungaiyu dump yards [68]. This creates severe soil and air pollution, and causes several health hazards, including respiratory disorders and cancers, for the city residents [38].

\subsection{US Extent and Level Prediction for 2027}

The obtained $K_{\text {location }}$ and $K_{\text {quantity }}$ for comparison between the modelled and classified LULC for 2016 were $84 \%$ and $81 \%$, respectively. These values indicate a high level of accuracy for the calibrated UEPM for urban extent prediction for 2016 in Chennai [26,34,58,59].

The predicted LULC for 2027 is shown in Figure 5. It shows an increase in the projected urban area of $12,805.58$ ha $(22.06 \%)$ from 2016 (Table 5). The vegetation and agriculture classes are predicted to decrease to 3961.66 ha $(66.29 \%)$ and 701.35 ha $(87.44 \%)$, respectively. This is associated with a transition of 4883.09 ha agricultural lands and 7792.9 ha vegetation areas to urban areas, between 2016 and 2027 (Figure 6 and Table 5). The increase of bare land i.e., 1570.12 ha (57.31\%) will occur as a consequence of the transitions from vegetation, water bodies, and agriculture land (Table 5). Thus, the bare land will increase at the expense of vegetation and agricultural lands and will potentially lead to the loss of important ecosystem services.

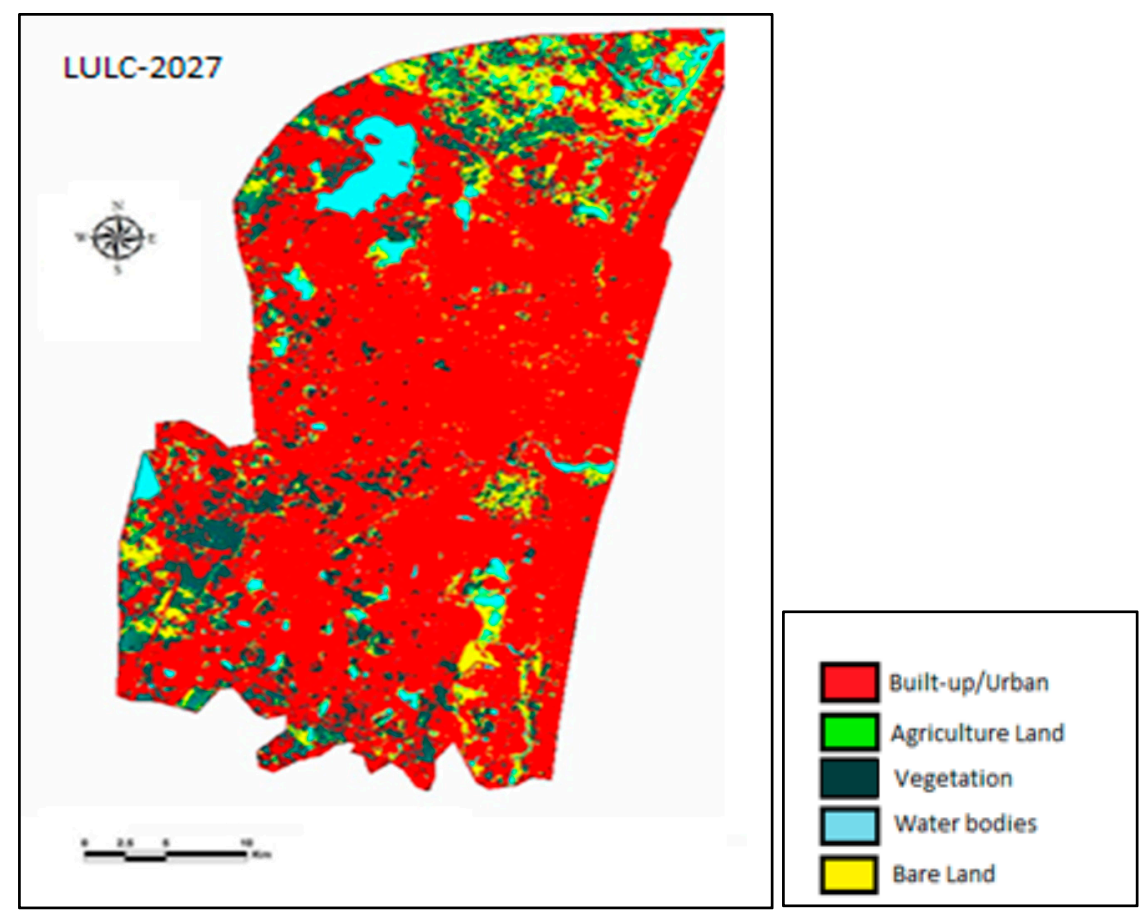

Figure 5. Simulated LULC map for the year 2027. 
Table 5. Comparison of the LULC areas of three study periods, i.e., 1991, 2003 and 2016, with the predicted LULC areas of Chennai for 2027.

\begin{tabular}{ccccccc}
\hline Land-Use Class & \multirow{2}{*}{$\mathbf{1 9 9 1}$} & \multirow{2}{*}{$\mathbf{2 0 0 3}$} & $\mathbf{2 0 1 6}$ & $\mathbf{2 0 2 7}$ & \multicolumn{2}{c}{ Forecasted LULC in 2027 } \\
\cline { 6 - 7 } & & & & & ha & \% \\
\hline Built-up/urban & $20,110.61$ & $39,965.51$ & $58,030.42$ & $70,836.76$ & $12,805.58$ & 22.06 \\
Agriculture & 9387.15 & $22,857.47$ & 5584.44 & 701.35 & -4883.09 & -87.44 \\
Vegetation & $21,677.89$ & 9296.41 & $11,754.56$ & 3961.66 & -7792.9 & -66.29 \\
Water bodies & 5320.48 & 6772.27 & 6120.62 & 5420.62 & -700 & -11.43 \\
Bare land & $25,992.02$ & 3596.48 & 998.10 & 1570.12 & 572.02 & 57.31 \\
\hline Total & $82,488.16$ & $82,488.16$ & $82,488.16$ & $82,488.16$ & - & - \\
\hline
\end{tabular}

The urban areas covered $70.35 \%$ of the total landscape in 2016, which is predicted to increase to $85.87 \%$ in 2027 (Figure 6). The Renyi's entropy value of the predicted urban area in 2027 is expected to be 1.7, which is above the range value of 1 [35], indicating a tremendous level of US. Overall, the extent and level of US for the coming 12 years is expected to increase at an alarming rate and cause degradation of urban ecosystem services.

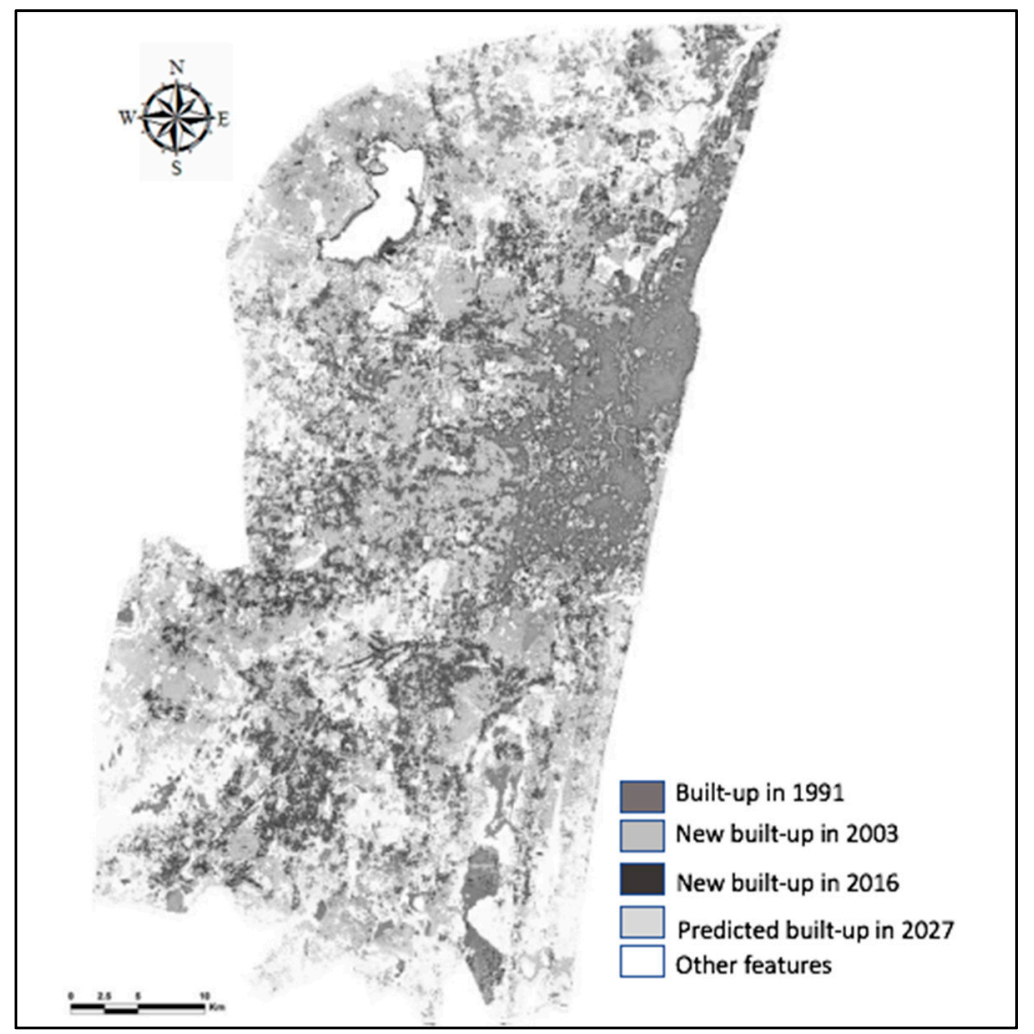

Figure 6. Urban sprawl, i.e., changes in urban extents between 1991-2027.

\section{Concluding Remarks}

We found fragmented urban growth in the outskirts of Chennai city, with the transformation of vegetation cover and agriculture land into built-up settlements. This alarming extent and level of US will have adverse impacts on the natural resources and land of Chennai. The combined application of geographic information systems, remote sensing, urban change modelling, landscape metrics and entropy measures proved to be a useful and efficient approach for our assessment and modelling US for the Chennai city. Consequently, this study contributes with indicators and metrics to monitor this US in Chennai. It also provides relevant information for sustainable urban growth and efficient 
urban planning as well as for mitigation of environmental impacts in Chennai. To conclude, our study provides quantitative measures for urban planning and management authorities for mitigating social-ecological consequences of US and preventing loss of urban ecosystem services.

Acknowledgments: The study was conduct as a part of the "Rajchandar Padmanaban Ph.D. program" in Information Management School (NOVA IMS), Universidade Nova de Lisboa. The authors thank NOVA Information Management School (NOVA IMS), Universidade Nova de Lisboa and Institute for Geoinformatics (IFGI), Westfälische Wilhelms-Universität Münster, Germany for the logistics and computation support for the study.

Author Contributions: Rajchandar Padmanaban and Pedro Cabral have conceived the study. Rajchandar Padmanaban, Oraib Almegdadi and Wang Shuangao conducted image processing, classification and accuracy assessment under the supervision of Avit K. Bhowmik and Pedro Cabral. Rajchandar Padmanaban and Avit K. Bhowmik wrote the paper, Pedro Cabral, Alexander Zamyatin, Oraib Almegdadi and Wang Shuangao revised the paper.

Conflicts of Interest: The authors declare no conflict of interest.

\section{References}

1. Stow, D.A.; Hope, A.; McGuire, D.; Verbyla, D.; Gamon, J.; Huemmrich, F.; Houston, S.; Racine, C.; Sturm, M.; Tape, K.; et al. Remote sensing of vegetation and land-cover change in Arctic Tundra Ecosystems. Remote Sens. Environ. 2004, 89, 281-308. [CrossRef]

2. Lambin, E.F.; Turner, B.L.; Geist, H.J.; Agbola, S.B.; Angelsen, A.; Folke, C.; Bruce, J.W.; Coomes, O.T.; Dirzo, R.; George, P.S.; et al. The causes of land-use and land-cover change: Moving beyond the myths. Glob. Environ. Chang. 2001, 11, 261-269. [CrossRef]

3. Visalatchi, A.; Padmanaban, R. Land Use and Land Cover Mapping and Shore Line Changes Studies in Tuticorin Coastal Area Using Remote Sensing. Int. J. Remote Sens. 2012, 1, 1-12.

4. Monishiya, B.G.; Padmanaban, R. Mapping and change detection analysis of marine resources in Tuicorin and Vembar group of Islands using remote sensing. Int. J. Adv. For. Sci. Manag. 2012, 1, 1-16.

5. Squires, G.D. Urban Sprawl Causes, Consequences and Policy Responses; Corrier, K., Gorham, W., Hadley, J., Harrell, A.V., Reischauer, R.D., Rogers, J.R., Peterson, G.E., Nightingale, D.S., Eds.; The Urban Institute Press: Washington, DC, USA, 2002.

6. Cabral, P.; Feger, C.; Levrel, H.; Chambolle, M.; Basque, D. Assessing the impact of land-cover changes on ecosystem services: A first step toward integrative planning in Bordeaux, France. Ecosyst. Serv. 2016, 22, 318-327. [CrossRef]

7. Schafer, A.; Victor, D.G. The future mobility of the world population. Transp. Res. Part A Policy Pract. 2000, 34, 171-205. [CrossRef]

8. Dewan, A.M.; Corner, R.J. Spatiotemporal Analysis of Urban Growth, Sprawl and Structure. In Dhaka Megacity: Geospatial Perspectives on Urbanisation, Enviornment and Health; Dewan, A., Corner, R.J., Eds.; Springer Science and Business Media: Dordretch, The Netherlands; pp. 99-121.

9. Megahed, Y.; Cabral, P.; Silva, J.; Caetano, M. Land Cover Mapping Analysis and Urban Growth Modelling Using Remote Sensing Techniques in Greater Cairo Region-Egypt. ISPRS Int. J. Geo-Inf. 2015, 4, 1750-1769. [CrossRef]

10. Cadenasso, M.L.; Pickett, S.T.A.; Schwarz, K. Spatial heterogeneity in urban ecosystems: Conceptualizing land cover and a framework for classification. Front. Ecol. Environ. 2007, 5, 80-88. [CrossRef]

11. Zhang, Q.; Wang, J.; Peng, X.; Gong, P.; Shi, P. Urban built-up land change detection with road density and spectral information from multi-temporal Landsat TM data. Int. J. Remote Sens. 2002, 23, 3057-3078. [CrossRef]

12. Luck, M.; Wu, J.G. A gradient analysis of urban landscape pattern: A case study from the Phoenix metropolitan region, Arizona, USA. Landsc. Ecol. 2002, 17, 327-340. [CrossRef]

13. Cabral, P.; Santos, J.A.; Augusto, G. Monitoring Urban Sprawl and the National Ecological Reserve in Sintra-Cascais, Portugal: Multiple OLS Linear Regression Model Evaluation. J. Urban Plan. Dev. 2011, 137, 346-353. [CrossRef]

14. Jayaprakash, M.; Senthil Kumar, R.; Giridharan, L.; Sujitha, S.B.; Sarkar, S.K.; Jonathan, M.P. Bioaccumulation of metals in fish species from water and sediments in macrotidal Ennore creek, Chennai, SE coast of India: A metropolitan city effect. Ecotoxicol. Environ. Saf. 2015, 120, 243-255. [CrossRef] [PubMed] 
15. Gowri, V.S.; Ramachandran, S.; Ramesh, R.; Pramiladevi, I.R.; Krishnaveni, K. Application of GIS in the study of mass transport of pollutants by Adyar and Cooum Rivers in Chennai, Tamilnadu. Environ. Monit. Assess. 2008, 138, 41-49. [CrossRef] [PubMed]

16. Aithal, B.H.; Ramachandra, T.V. Visualization of Urban Growth Pattern in Chennai Using Geoinformatics and Spatial Metrics. J. Indian Soc. Remote Sens. 2016, 44, 617-633. [CrossRef]

17. Jat, M.K.; Garg, P.K.; Khare, D. Monitoring and modelling of urban sprawl using remote sensing and GIS techniques. Int. J. Appl. Earth Obs. Geoinf. 2008, 10, 26-43. [CrossRef]

18. Sudhira, H.S.; Ramachandra, T.V.; Jagadish, K.S. Urban sprawl pattern recognition and modelling using GIS. In Proceedings of the 2003 Map India, New Delhi, India, 28-30 January 2003; pp. 1-9.

19. Moghadam, H.S.; Helbich, M. Spatiotemporal urbanization processes in the megacity of Mumbai, India: A Markov chains-cellular automata urban growth model. Appl. Geogr. 2013, 40, 140-149. [CrossRef]

20. Dewan, A.M.; Yamaguchi, Y. Land use and land cover change in Greater Dhaka, Bangladesh: Using remote sensing to promote sustainable urbanization. Appl. Geogr. 2009, 29, 390-401. [CrossRef]

21. Dewan, A.M.; Yamaguchi, Y.; Rahman, M.Z. Dynamics of land use/cover changes and the analysis of landscape fragmentation in Dhaka Metropolitan, Bangladesh. GeoJournal 2012, 77, 315-330. [CrossRef]

22. Poelmans, L.; Van Rompaey, A. Computers, Environment and Urban Systems Complexity and performance of urban expansion models. Comput. Environ. Urban Syst. 2010, 34, 17-27. [CrossRef]

23. Padmanaban, R. Integrating of Urban Growth Modelling and Utility Management System using Spatio Temporal Data Mining. Int. J. Adv. Earth Sci. Eng. 2012, 1, 13-15.

24. Padmanaban, R. Modelling the Transformation of Land use and Monitoring and Mapping of Environmental Impact with the help of Remote Sensing and GIS. Int. J. Adv. Altern. Energy Environ. Ecol. 2012, 1, 36-38.

25. Herold, M.; Goldstein, N.C.; Clarke, K.C. The spatiotemporal form of urban growth: Measurement, analysis and modeling. Remote Sens. Environ. 2003, 86, 286-302. [CrossRef]

26. De Oliveira Filho, F.J.B.; Metzger, J.P. Thresholds in landscape structure for three common deforestation patterns in the Brazilian Amazon. Landsc. Ecol. 2006, 21, 1061-1073. [CrossRef]

27. Tv, R.; Aithal, B.H.; Sanna, D.D. Insights to urban dynamics through landscape spatial pattern analysis. Int. J. Appl. Euarth Obs. Geoinf. 2012, 18, 329-343. [CrossRef]

28. Byomkesh, T.; Nakagoshi, N.; Dewan, A.M. Urbanization and green space dynamics in Greater Dhaka, Bangladesh. Landsc. Ecol. Eng. 2012, 8, 45-58. [CrossRef]

29. Ferdinent, J.; Padmanaban, R. Development of a Methodology to Estimate Biomass from Tree Height Using Airborne Digital Image. Int. J. Adv. Remote Sens. GIS 2013, 2, 49-58.

30. Sabet Sarvestani, M.; Ibrahim, A.L.; Kanaroglou, P. Three decades of urban growth in the city of Shiraz, Iran: A remote sensing and geographic information systems application. Cities 2011, 28, 320-329. [CrossRef]

31. Fistola, R. Urban entropy vs. sustainability: A new town planning perspective. WIT Trans. Ecol. Environ. 2012, 155, 195-204.

32. Ji, W.; Ma, J.; Twibell, R.W.; Underhill, K. Characterizing urban sprawl using multi-stage remote sensing images and landscape metrics. Comput. Environ. Urban Syst. 2006, 30, 861-879. [CrossRef]

33. Cabral, P.; Augusto, G.; Tewolde, M.; Araya, Y. Entropy in Urban Systems. Entropy 2013, 15, 5223-5236. [CrossRef]

34. Tewolde, M.G.; Cabral, P. Urban sprawl analysis and modeling in Asmara, Eritrea. Remote Sens. 2011, 3, 2148-2165. [CrossRef]

35. Fan, Y.; Yu, G.; He, Z.; Yu, H.; Bai, R.; Yang, L.; Wu, D. Entropies of the Chinese Land Use/Cover Change from 1990 to 2010 at a County Level. Entropy 2017, 19, 51. [CrossRef]

36. Dewan, A.M.; Humayun, K.; Nahar, M.K.; Rahman, Z. Urbanisation and environmental degradation in Dhaka Metropolitan Area of Bangladesh. Environ. Sustain. Dev. 2012, 11, 118-147. [CrossRef]

37. Shanmugam, P.; Neelamani, S.; Ahn, Y.H.; Philip, L.; Hong, G.H. Assessment of the levels of coastal marine pollution of Chennai city, Southern India. Water Resour. Manag. 2007, 21, 1187-1206. [CrossRef]

38. Raman, N.; Narayanan, D.S. Impact of Solid Waste Effect on Ground Water and Soil Quality Nearer to Pallavaram Solid Waste Landfill Site in Chennai. Rasayan 2008, 1, 828-836.

39. Arabindoo, P. "City of sand": Stately Re-Imagination of Marina Beach in Chennai. Int. J. Urban Reg. Res. 2011, 35, 379-401. [CrossRef] 
40. Rani, C.S.S.; Rema, M.; Deepa, R.; Premalatha, G.; Ravikumar, R.; Mohan, A.; Ramu, M.; Saroja, R.; Kayalvizhi, G.; Mohan, V. The Chennai Urban Population Study (Cups)—Methodological Details—(Cups Paper No. 1). Int. J. Diabetes Dev. Ctries. 1999, 19, 149-155.

41. Padmanaban, R.; Sudalaimuthu, K. Marine Fishery Information System and Aquaculture Site Selection Using Remote Sensing and GIS. Int. J. Adv. Remote Sens. GIS 2012, 1, 20-33.

42. Padmanaban, R.; Thomas, V. Inventory of Liquefaction Area and Risk Assessment Region Using Remote Sensing. Int. J. Adv. Remote Sens. GIS 2013, 2, 198-204.

43. Huttner, S.; Bruse, M.; Dostal, P. Using ENVI-met to simulate the impact of global warming on the mi-croclimate in central European cities. In Proceedings of the 5th Japanese-German Meeting on Urban Climatology, Freiburg im Breisgau, Germany, 6-8 October 2008; Volume 18, pp. 307-312.

44. Yee, K.M.; Wai, K.P.; Jinhyung, B.; Uong, C.C. Land Use and Land Cover Mapping Based on Band Ratioing with Subpixel Classification by Support Vector Machine Techniques (A Case Study on Ngamoeyeik Dam Area, Yangon Region). J. Geol. Resour. Eng. 2016, 4, 127-133.

45. Loveland, T.R.; Reed, B.C.; Brown, J.F.; Ohlen, D.O.; Zhu, Z.; Yang, L.; Merchant, J.W. Development of a global land cover characteristics database and IGBP DISCover from $1 \mathrm{~km}$ AVHRR data. Int. J. Remote Sens. 2000, 21, 1303-1330. [CrossRef]

46. Vincenzi, S.; Zucchetta, M.; Franzoi, P.; Pellizzato, M.; Pranovi, F.; De Leo, G.A.; Torricelli, P. Application of a Random Forest algorithm to predict spatial distribution of the potential yield of Ruditapes philippinarum in the Venice lagoon, Italy. Ecol. Model. 2011, 222, 1471-1478. [CrossRef]

47. Venkatesan, G.; Padmanaban, R. Possibility Studies and Parameter Finding for Interlinking of Thamirabarani and Vaigai Rivers in Tamil Nadu, India. Int. J. Adv. Earth Sci. Eng. 2012, 1, 16-26.

48. Congalton, R.G. A review of assessing the accuracy of classifications of remotely sensed data. Remote Sens. Environ. 1991, 37, 35-46. [CrossRef]

49. Kong, F.; Yin, H.; Nakagoshi, N. Using GIS and landscape metrics in the hedonic price modeling of the amenity value of urban green space: A case study in Jinan City, China. Landsc. Urban Plan. 2007, 79, $240-252$. [CrossRef]

50. UMass Landscape Ecology Lab FRAGSTATS: Spatial Pattern Analysis Program for Categorical Maps. Available online: http://www.umass.edu/landeco/research/fragstats/fragstats.html (accessed on 20 December 2016).

51. Herold, M.; Scepan, J.; Clarke, K.C. The use of remote sensing and landscape metrics to describe structures and changes in urban land uses. Environ. Plan. A 2002, 34, 1443-1458. [CrossRef]

52. Tsallis, C. Possible generalization of Boltzmann-Gibbs statistics. J. Stat. Phys. 1988, 52, 479-487. [CrossRef]

53. Drius, M.; Malavasi, M.; Acosta, A.T.R.; Ricotta, C.; Carranza, M.L. Boundary-based analysis for the assessment of coastal dune landscape integrity over time. Appl. Geogr. 2013, 45, 41-48. [CrossRef]

54. Pontius, R.G. Quantification Error Versus Location Error in Comparison of Categorical Maps. Photogramm. Eng. Remote Sens. 2000, 1610, 1011-1016.

55. Pontius, R.G., Jr.; Boersma, W.; Clarke, K.; Nijs, T.; De Dietzel, C.; Duan, Z.; Fotsing, E.; Goldstein, N.; Kok, K.; Koomen, E.; et al. Comparing the input, output, and validation maps for several models of land change. Ann. Reg. Sci. 2008, 42, 11-37. [CrossRef]

56. Martins, V.N.; Cabral, P.; Silva, D.S. System Sciences Urban modelling for seismic prone areas: The case study of Vila Franca do Campo (Azores Archipelago, Portugal). Nat. Hazards Earth Syst. Sci. 2012, 12, 2731-2741. [CrossRef]

57. Zyczkowski, K. Renyi extrapolation of Shannon entropy. Open Syst. Inf. Dyn. 2003, 10, 297-310. [CrossRef]

58. Langley, S.K.; Cheshire, H.M.; Humes, K.S. A comparison of single date and multitemporal satellite image classifications in a semi-arid grassland. J. Arid Environ. 2001, 49, 401-411. [CrossRef]

59. Araya, Y.H.; Cabral, P. Analysis and modeling of urban land cover change in Setúbal and Sesimbra, Portugal. Remote Sens. 2010, 2, 1549-1563. [CrossRef]

60. Chaves, A.B.; Lakshumanan, C. Remote Sensing and GIS-Based Integrated Study and Analysis for Mangrove-Wetland Restoration in Ennore Creek, Chennai, South India. In Proceedings of the Taal2007: The 12th World Lake Conference, Jaipur, India, 29 October-2 November 2008; pp. 685-690.

61. Tanaka, N. Vegetation bioshields for tsunami mitigation: Review of effectiveness, limitations, construction, and sustainable management. Landsc. Ecol. Eng. 2009, 5, 71-79. [CrossRef] 
62. Kerr, A.M.; Baird, A.H.; Bhalla, R.S.; Srinivas, V. Reply to “Using remote sensing to assess the protective role of coastal woody vegetation against tsunami waves". Int. J. Remote Sens. 2009, 30, 3817-3820. [CrossRef]

63. Dhorde, A.; Gadgil, A. Long-term temperature trends at four largest cities of India during the twentieth Century. J. Ind. Geophys. Union 2009, 13, 85-97.

64. Kim Oanh, N.T.; Upadhyay, N.; Zhuang, Y.H.; Hao, Z.P.; Murthy, D.V.S.; Lestari, P.; Villarin, J.T.; Chengchua, K.; Co, H.X.; Dung, N.T.; et al. Particulate air pollution in six Asian cities: Spatial and temporal distributions, and associated sources. Atmos. Environ. 2006, 40, 3367-3380. [CrossRef]

65. Chithra, V.S.; Shiva Nagendra, S.M. Indoor air quality investigations in a naturally ventilated school building located close to an urban roadway in Chennai, India. Build. Environ. 2012, 54, 159-167. [CrossRef]

66. Padmanaban, R.; Kumar, R. Mapping and Analysis of Marine Pollution in Tuticorin Coastal Area Using Remote Sensing and GIS. Int. J. Adv. Remote Sens. GIS 2012, 1, 34-48.

67. Giridharan, L.; Venugopal, T.; Jayaprakash, M. Evaluation of the seasonal variation on the geochemical parameters and quality assessment of the groundwater in the proximity of River Cooum, Chennai, India. Environ. Monit. Assess. 2008, 143, 161-178. [CrossRef] [PubMed]

68. Vasanthi, P.; Kaliappan, S.; Srinivasaraghavan, R. Impact of poor solid waste management on ground water. Environ. Monit. Assess. 2008, 143, 227-238. [CrossRef] [PubMed]

(C) 2017 by the authors. Licensee MDPI, Basel, Switzerland. This article is an open access article distributed under the terms and conditions of the Creative Commons Attribution (CC BY) license (http:/ / creativecommons.org/licenses/by/4.0/). 